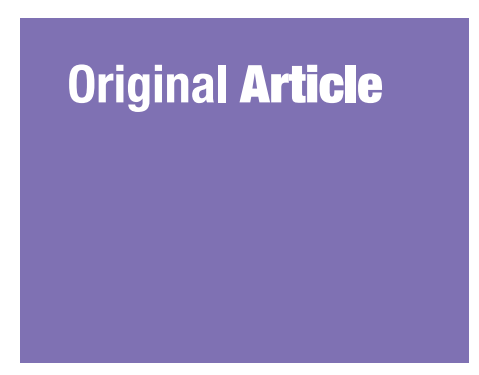

Submitted: 8 Oct 2016 Accepted: 5 Apr 2017 Online: 30 Jun 2017

\section{In Vitro Cytotoxic and Anticancer Effects of Zamzam Water in Human Lung Cancer (A594) Cell Line}

\author{
Ulfat M. Omar, Huda A. Al Doghaither, Sawsan A. Rahimulddin, \\ Shiekhah M. Al Zahrani, Ayat B. Al-Ghafarı
}

Department of Biochemistry, Faculty of Sciences, King Abdulaziz University, Jeddah, Saudi Arabia

To cite this article: Omar UM, Al Doghaither HA, Rahimulddin SA, Al Zahrani SM, Al-Ghafari AB. In vitro cytotoxic and anticancer effects of Zamzam water in human lung cancer (A594) cell line. Malays J Med Sci. 2017;24(3):15-25. https://doi.org/10.21315/mjms2017.24.3.3

To link to this article: http://doi.org/10.21315/mjms2017.24.3.3

\begin{abstract}
Background: Zamzam water is naturally alkaline and rich in a variety of minerals which may represent a powerful tool for cancer therapy. In this research, the cytotoxic effects of Zamzam water were investigated in human lung cancer (A549) cell line and compared with human skin fibroblasts (HSF).

Methods: Two different preparations of Zamzam water were used: $\mathrm{Z1}$, with $\mathbf{p H}$ adjusted to 7.2 and $\mathrm{Z2}$, with no $\mathrm{pH}$ adjustment. The effects of both treatments on the morphology of the A549 and HSF cell lines were investigated. The cell viability of HSF and A549 cells was identified by the MTT assay and trypan blue exclusion. Detection of apoptotic cells and cell cycle analyses were determined using flow cytometry. Moreover, reactive oxygen species (ROS) were measured for both cell lines.

Results: Both Zamzam water treatments, $\mathrm{Z}_{1}$ and $\mathrm{Z}_{2}$ showed reductions in the cell viability of A549 cells. Cell death occurred via necrosis among cells treated with Z2. Cell cycle arrest occurred in the Go/G1 phases for cells treated with Z2. Cellular and mitochondrial ROS productions were not affected by either treatment.

Conclusion: Our findings indicate that Zamzam water might have potential therapeutic efficacy for lung cancer.
\end{abstract}

Keywords: alkaline water, Annexin $V$, cell cycle, cytotoxic, lung cancer

\section{Introduction}

Lung cancer is a life-threatening disease and has currently become the number one killer among cancers worldwide (1). It is the leading cause of cancer-related mortality in the United States, China and the Arab countries (2). Lung cancer has a dismal five-year survival rate of $15 \%$ (3). Timely detection, as well as diet and food supplements have been associated with an increase or decrease in lung cancer risk.

Water has been used historically as a healer due to its many properties, such as a high mineral content and high pH value (4). Roman bath water and the Dead Sea water were used to heal many skin problems, and deep-sea water has been mentioned as hydrotherapy for various body systems (5) and for inhibiting metastasis in human breast cancer cell lines (6). Moreover, alkaline water was reported to reduce oxidative stress and hemorrhagic gastric lesions in rats (7).

Zamzam water is naturally alkaline and it comes from an ancient well located in Makkah, Saudi Arabia. Millions of people have used it since the time of Prophet Ibrahim as a holy natural water for its exceptional healing 
properties. It is rich in a variety of minerals and has a high $\mathrm{pH}$ value (average $\mathrm{pH}$ of 8) (8). Moreover, no bacteria can form at the source of or in Zamzam water (9). It was reported that Zamzam water has the ability to prevent the formation of renal stones in kidney-stone induced rats (10) and to reduce the oxidative stress in type 2 diabetic patients (11).

Oxidative stress is associated with many diseases and their complications. One reason of such an oxidant/antioxidants imbalance is dietary deficiencies in essential elements, which are important components of antioxidant enzymes (12). The aim of this study is to illustrate the cytotoxic and anticancer properties of Zamzam water in human lung cancer cell line (A549).

\section{Materials and Methods}

\section{Chemicals}

High glucose Dulbecco's Modified Eagle's medium powder (DMEM), fetal bovine serum (FBS) and trypan blue were purchased from Hyclone, USA. Propidium iodide (PI), 3-(4,5-Dimethylthiazol-2-yl)-2,5diphenyltetrazolium bromide (MTT), and L-glutamine were purchased from SigmaAldrich Co, Poole, UK. Trypsin/EDTA, antibiotics (penicillin/streptomycin), and non-essential amino acids (NEAAs) were purchased from Gibco, Canada. Phosphatebuffered saline (PBS) tablets were purchased from Oxoid, Hampshire, UK. RNase and Annexin V-FITC Apoptosis Detection Kit were purchased from Abcam, UK. MitoSOX red and 2',7'-Dihydrodichlorofluorescein diacetate (CMH2DCFDA) were obtained from Invitrogen, Paisley, UK.

\section{Cell lines}

Human lung cancer cell line (A549) was purchased from the immunology laboratory, King Fahad Medical Research Center (KFMRC), and normal human skin fibroblast (HSF) cell line was purchased from the virology laboratory, King Abdulaziz University Hospital, Jeddah, Saudi Arabia. The study was approved by the Biochemistry Department and the Permanent committee for academic council's affairs at king Abdulaziz University (91831/37/D).

\section{Zamzam water source}

Zamzam water was obtained directly from Zamzam well, which is located within the Holy Mosque in Makkah, Saudi Arabia, 20 m (66 ft) east of the Kaaba. The well is about $30 \mathrm{~m}$ (98 ft)

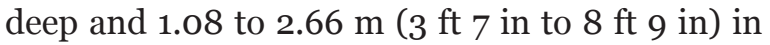
diameter. The water was stored in sterilised glass bottles and kept at room temperature until it was used.

\section{Preparation of culture media}

DMEM growth media stock was supplemented with 10\% FBS, 1\% L-glutamine, $1 \%$ antibiotics, and $1 \%$ NEAAs.

\section{Preparation of Zamzam water treatments and the negative control}

In this study, two different Zamzam water samples, designated $Z_{1}$ and $Z$ 2, and one negative control were prepared. To prepare $\mathrm{Z}_{1}$ and $\mathrm{Z}_{2}$ treatments, a PBS tablet was dissolved in $800 \mathrm{ml}$ of Zamzam water and the $\mathrm{pH}$ was either adjusted to $7.2(\mathrm{Z} 1)$ or not adjusted $(\mathrm{pH}=8, \mathrm{Z} 2)$. The negative control was PBS only.

\section{Morphological changes}

A549 and HSF cells were seeded in $25 \mathrm{~cm}^{2}$ flasks at a concentration of $8 \times 10^{5}$ cells $/ \mathrm{ml}$. After $24 \mathrm{~h}$ of incubation, changes in cell morphology were photographed using a Nikon Eclipse microscope at 10x magnification for $\mathrm{Z}_{1}$ and $\mathrm{Z}_{2}$ and were compared to the control.

\section{Cell viability assay}

\section{Trypan blue exclusion}

A549 and HSF cells were treated under the same conditions described in the (morphological changes) section. After $24 \mathrm{~h}$, when the cultured cells were $60 \%-70 \%$ confluent, they were treated with trypan blue dye (0.2\%) and counted with a hemocytometer.

\section{MTT assay}

Three independent experiments were performed to assess the cytotoxic effects of Zamzam water on A549 and HSF cells. A549 and HSF cells were seeded in a 96-well tissue culture plate at a concentration of $1 \times 10^{4}$ cells/ well and incubated for $24 \mathrm{~h}$ at $37{ }^{\circ} \mathrm{C} / 5 \% \mathrm{CO}_{2}$. After, the culture medium was replaced with $200 \mu \mathrm{l}$ of $\mathrm{Z} 1$ or Z2 or with $200 \mu \mathrm{l}$ of PBS only as a negative control. MTT assay was performed by adding $20 \mu \mathrm{l}$ of MTT dye and incubated for $2 \mathrm{~h}$ at $37^{\circ} \mathrm{C} / 5 \% \mathrm{CO}_{2}$. Then, treatments were discarded 
Original Article | Anticancer effects of Zamzam water in lung cancer cell line

and the precipitates were dissolved in $200 \mu \mathrm{l}$ of isopropyl. The developed colour intensity was measured at $490 \mathrm{~nm}$ using a BioTek microplate reader.

\section{Determination of cell death type by annexin-V/ PI assay}

To detect early and late apoptosis in A549 and HSF cell lines, $8 \times 10^{5}$ cells $/ \mathrm{ml}$ were seeded in $25 \mathrm{~cm}^{2}$ flasks until they became $70 \%$ confluent. After, cells were incubated with $\mathrm{Z}_{1}$ or $\mathrm{Z}_{2}$ and with the negative control medium for $24 \mathrm{~h}$. Then, the annexin-V/PI assay was carried out according to the manufacture instructions using a Beckman Coulter flow cytometer to acquire a minimum of 10,000 events in the gated regions. For cells labelled with annexin V-FITC, the emission wavelength was $520 \mathrm{~nm}$; meanwhile, for cells labelled with PI, an emission wavelength of $620 \mathrm{~nm}$ was used.

\section{Cell cycle analysis}

A549 and HSF cells were seeded in 25 $\mathrm{cm}^{2}$ flasks at a concentration of $8 \times 10^{5}$ cells/ $\mathrm{ml}$. When cells were $60 \%-70 \%$ confluent, they were treated with $\mathrm{Z}_{1}$ and $\mathrm{Z} 2$ for $24 \mathrm{~h}$ followed by trypsinisation. Pellets were washed twice with PBS then cells were fixed with $1 \mathrm{ml}$ of ice-cold fixing buffer (70\% ethanol in PBS) and incubated overnight at $4{ }^{\circ} \mathrm{C}$. After $24 \mathrm{~h}$, the fixation buffer was discarded and cells were re-suspended in $500 \mu \mathrm{l}$ PBS followed by $5 \mu \mathrm{l}$ of $5 \mathrm{mM}$ RNase. Cells were incubated for $30 \mathrm{~min}$ at $37{ }^{\circ} \mathrm{C}$, dyed with $5 \mu \mathrm{l}$ PI $(1 \mathrm{mg} / \mathrm{ml})$, and analysed with the BD FACSCalibur flow cytometer. At least, 10,000 events were acquired in the list mode using an emission wavelength of $620 \mathrm{~nm}$.

\section{Measurement of cellular reactive oxygen species (ROS)}

ROS levels in A549 were measured using the $\mathrm{H}_{2}$ DCFDA dye. A549 cells were seeded in $25 \mathrm{~cm}^{2}$ flasks at a density of $8 \times 10^{5}$ cells/ $\mathrm{ml}$ and treated with $\mathrm{Z}_{1}$ and $\mathrm{Z}_{2}$ culture media for $24 \mathrm{~h}$. Cells were incubated in the dark with $5 \mu \mathrm{l}$ of DCFDA for $30 \mathrm{~min}$ at $37{ }^{\circ} \mathrm{C} / 5 \% \mathrm{CO}_{2}$. DCF fluorescence was read at an excitation wavelength of $485 \mathrm{~nm}$ and at an emission wavelength of $528 \mathrm{~nm}$ using the BioTek fluorescence microplate reader.

\section{Measurement of mitochondrial reactive oxygen species (mtROS)}

The superoxide levels in A549 cell line incubated with $\mathrm{Z}_{1}$ and $\mathrm{Z}_{2}$ were measured with
MitoSOX dye using the BioTek fluorescence microplate reader according to the manufacture's instructions. The resulting red fluorescence was detected at excitation and emission wavelengths of $530 \mathrm{~nm}$ and $590 \mathrm{~nm}$, respectively.

\section{Statistical analysis}

The data were analysed using GraphPad Prism software version 6. All experiments were performed at least three times to ensure reproducibility. Significant differences were evaluated using $P$-values by the Kruskal-Wallis test followed by Dunn's multiple comparison tests. The cut-off level for significance was $<0.05$.

\section{Results}

\section{Morphological changes}

The antiproliferative effects of the two Zamzam treatments ( $Z_{1}$ and $Z_{2}$ ) on $A_{549}$ and HSF cell lines are shown in Figures $1 \mathrm{~A}$ and $1 \mathrm{~B}$. The changes in the cell membranes of A549 cells were more obvious in the high-alkaline medium (Z2) than in the adjusted $\mathrm{pH}$ treatment (Z1). In contrast, the same treatments had no effect on HSF cells, which appeared intact when compared to the control.

\section{Cell viability assessment by trypan blue exclusion and MTT assay}

The effects of Zamzam water treatments on cell viability were assessed using a trypan blue cell count and MTT assay. In both assays, only Zamzam water treatment (Z2) was found to decrease cancer cell viability significantly in A549 cell line compared to the untreated control. In trypan blue cell count, A549 cell viability was reduced to $68.66 \%$ ( $\mathrm{Z} 1$ treatment) and 54\% ( $\mathrm{Z} 2$ treatment) (Figure 2A), whereas HSF cells showed no significant differences in the cell viability when incubated with $\mathrm{Z}_{1}$ and $\mathrm{Z}_{2}$ (103.66\% and 105.8\%, respectively).

MTT assay showed that the cancer cell viability was decreased to $79 \%$ and $73 \%$ after treatment with $Z_{1}$ and $Z_{2}$, respectively when compared to the untreated A549 cells (Figure 2B). The same treatment showed insignificant effects on the viability of the HSF cells (95.02\% and $97.9 \%$ with $\mathrm{Z} 1$ and $\mathrm{Z} 2$, respectively). 
A) A549
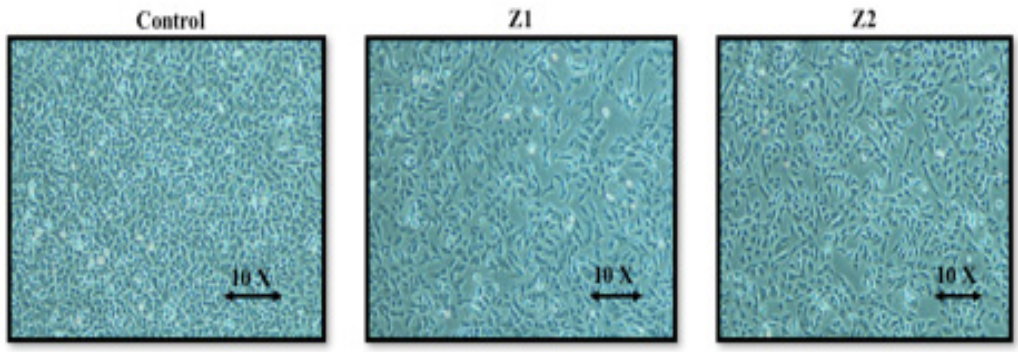

B) HSF
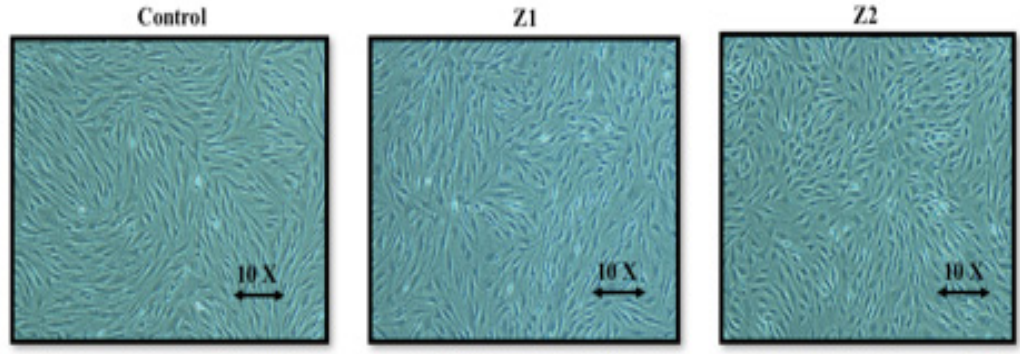

Figure 1. The effects of Zamzam water on A549 and HSF cells incubated for $24 \mathrm{~h}$ compared to untreated cells. A) A549 cells incubated with Z1 and Z2 compared to untreated cells. B) HSF cells treated with $\mathrm{Z}_{1}$ and $\mathrm{Z}_{2}$ treatments compared to untreated cells. Images were captured using light microscopy at $10 \times$ magnification

\section{A)Trypan blue}

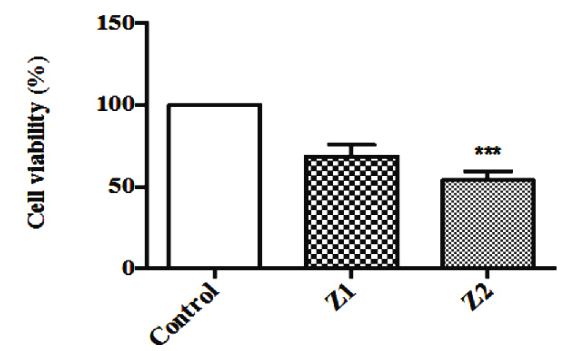

\section{B) MTT}

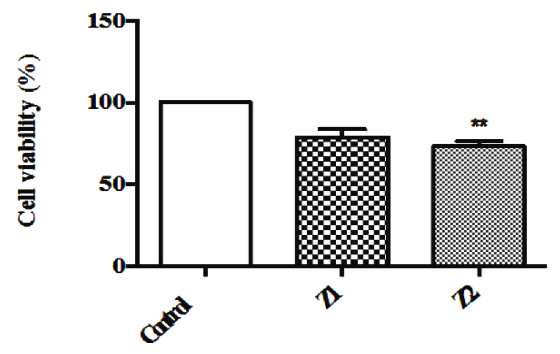

Figure 2. The cytotoxic effects of Zamzam water on A549 cell line by trypan blue and MTT assay. A) Trypan blue cell count of A549 cells treated with $Z_{1}$ and $Z_{2}$ compared to untreated cells. B) MTT results of A549 cells treated with $\mathrm{Z}_{1}$ and $\mathrm{Z}_{2}$ compared to untreated cells. The data represents the mean of three independent experiments $(n=3 \pm$ SEM). Comparisons of means were made using the Kruskal-Wallis test followed by Dunn's test $\left({ }^{* *} P \leq 0.01\right.$, ${ }^{* * *} P \leq$ 0.001) 
Original Article | Anticancer effects of Zamzam water in lung cancer cell line

\section{Determination of cell death type}

The necrosis phenomenon was significantly induced only in A549 cells treated with Zamzam water treatment (Z2) compared to the untreated control and $\mathrm{Z} 1$ treatment. The percentage of early apoptosis was $0.75 \%, 0.7 \%$, and $1 \%$ in the control, Z1, and $\mathrm{Z}_{2}$ treatments, respectively. In the late apoptotic stage, there was no significant increases between the untreated control cells and Z1-treated cells (1.5\% and $1.4 \%$, respectively), whereas in Z2-treated cells, the percentage of apoptosis increased to $3.9 \%$ compared to the untreated control. Regarding necrosis, only $\mathrm{Z}_{2}$ treatment showed a significant effect compared to the untreated control and $\mathrm{Z} 1$ treatment. The percentages of necrosis in A549 cells were 1.9\%, $4.7 \%$, and $6.65 \%(P<0.05)$ in the control, $\mathrm{Z} 1$, and $\mathrm{Z} 2$, treatments, respectively (Figures $3 \mathrm{~A}$ and $3 \mathrm{~B}$ ). For normal HSF cells, Zamzam water treatments did not show any significant effect in all apoptotic and necrotic stages. The percentage of early apoptosis in HSF remained as low as $3 \%$, $3.5 \%$, and $2.8 \%$ for the untreated control, $\mathrm{Z} 1$, and Z2 treatments, respectively, whereas in the late apoptotic stage, the percentages were $0.78 \%$, $1.32 \%$, and $0.85 \%$, respectively. In the necrotic stage, the lowest percentages were, $0.2 \%, 0.12 \%$, and $0.08 \%$ for the control and treated cells, respectively (Figures $3 \mathrm{C}$ and $3 \mathrm{D}$ ).

\section{Effect of Zamzam treatments on cell cycle}

For the cell cycle analysis, Z2 treatment showed a significant effect on A549 cells. There was a significant increase in the cell population treated with $\mathrm{Z} 2$ (arrest in the Go/G1 phase) while the $S$ phase was not affected by the treatment. The percentages of A549 cells in the Go/G1 phase were $38.6 \%, 37.9 \%$, and $52 \%$ for the control, $\mathrm{Z}_{1}$, and $\mathrm{Z}_{2}$ treatments, respectively. Moreover, the percentages of cells in the $S$ phase were $18.3 \%, 17 \%$, and $17.2 \%$, respectively, while in the G2 phase, the percentages were $10.8 \%$, $20 \%$, and $10.4 \%$ for the control, $\mathrm{Z}_{1}$ and $\mathrm{Z}_{2}$ treatments, respectively (Figure 4B).

In contrast to A549 cells, the same Zamzam water treatment used on normal HSF cells showed no significant effect $(P>0.05)$ in the $\mathrm{G} 1, \mathrm{~S}$, and G2 phases compared to the control, as presented in Figure 4D. The percentages of HSF cells in the G1 phase were $54.1 \%, 52.75 \%$, and $56.26 \%$ for the control, $\mathrm{Z} 1$, and $\mathrm{Z} 2$ treatments, respectively. The percentages of cells in the $\mathrm{S}$ phase were $17.33 \%, 17.33 \%$, and $12 \%$, while in the G2 phase, the percentages were $12.38 \%$, $10.7 \%$, and $12.22 \%$ for the controls, $Z 1$, and $Z_{2}$ treatments, respectively.

\section{Cellular and mitochondrial ROS measurement}

Cellular and mitochondrial ROS (superoxide anion) productions were not affected by $\mathrm{Z}_{1}$ and $\mathrm{Z}_{2}$ treatments when compared to the untreated control cells $(P>0.05)$ (Figure $5 \mathrm{~A})$. The intensity of cellular ROS formation by Z1 was 43.75 RFU, while the cellular ROS production of Z2 treatment was 46.75 RFU compared to the control, which was 51.25 RFU. Moreover, the florescent intensity of the mtROS formation of Z1 treatment was $16,067 \mathrm{RFU}$ while the mtROS 
A) $\mathbf{A 5 4 9}$
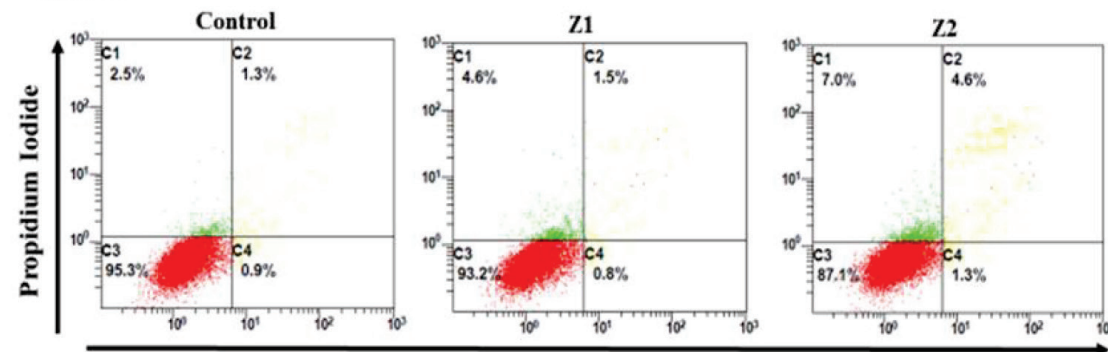

Annexin V-FITC

B) $\mathbf{A 5 4 9}$

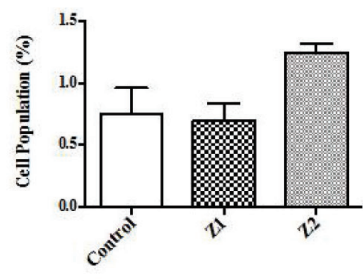

Early Apoptotic

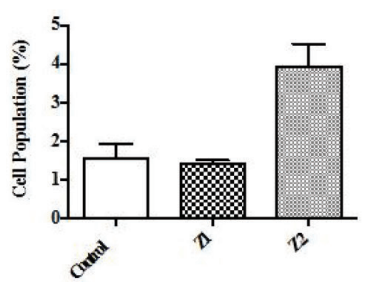

Late ApoptoticNecrotic

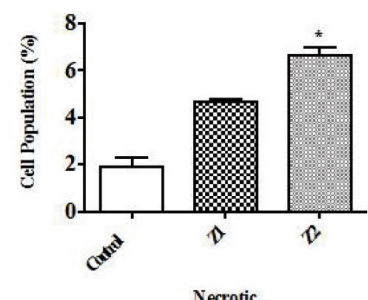

Necrotic

C) HSF

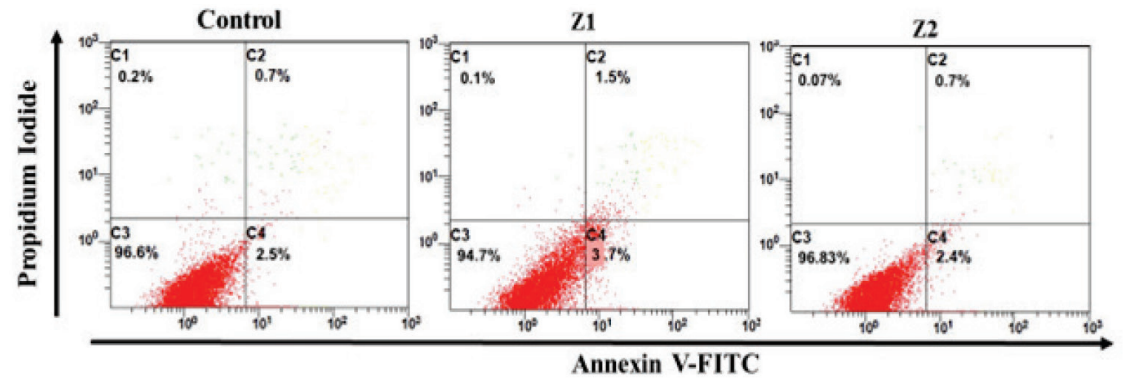

D) HSF

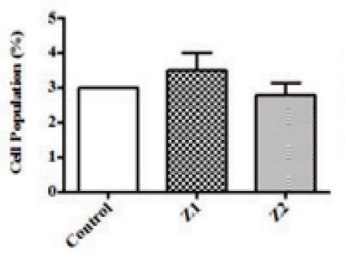

Early Apoptotic

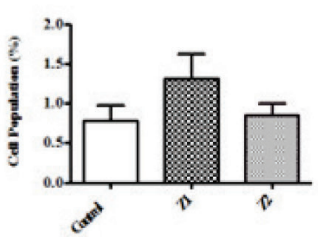

Late Apoptotic Necrotic

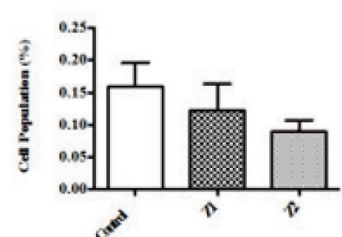

verrotic

Figure 3. Detection of cell deaths of A549 and HSF cells after treatment with Z1 and Z2 for $24 \mathrm{~h}$ by flow cytometry. Represented values are the means of three independent experiments $(n$ $=3 \pm$ SEM). Comparisons of means were made using the Kruskal-Wallis test followed by Dunn's test $\left({ }^{*} P<0.05\right)$. A) Flow cytometric analysis of annexin V/PI in A549 cells treated with $\mathrm{Z}_{1}$ and $\mathrm{Z} 2$ treatments for $24 \mathrm{~h}$. $\mathrm{C}_{1}-\mathrm{C}_{4}$ quadrants indicate: $\mathrm{C}_{1}=$ Cells stained with PI; C2 = Cells conjugated with annexin V and stained with PI; $\mathrm{C}_{3}=$ Healthy cells; and $\mathrm{C}_{4}=$ Cells conjugated with annexin V. B) Percentage of A549 cells in early apoptosis, late apoptotic/ necrotic cell death, and necrotic cell death pathways after treatment with $\mathrm{Z}_{1}$ and $\mathrm{Z} 2$ for 24 h. C) Flow cytometric analysis of annexin V/PI in HSF cells treated with different Z1 and Z2 for 24 h. C1- C4 quadrants indicate: $\mathrm{C} 1=$ Cells stained with PI; $\mathrm{C}_{2}=$ Cells conjugated with annexin $\mathrm{V}$ and stained with PI; $\mathrm{C}_{3}=$ Healthy cells; and $\mathrm{C}_{4}=$ Cells conjugated with annexin V. D) Percentage of HSF cells in early apoptosis, late apoptotic/necrotic cell death, and necrotic cell death pathways after treatment with $\mathrm{Z}_{1}$ and $\mathrm{Z} 2$ for $24 \mathrm{~h}$ 
Original Article | Anticancer effects of Zamzam water in lung cancer cell line

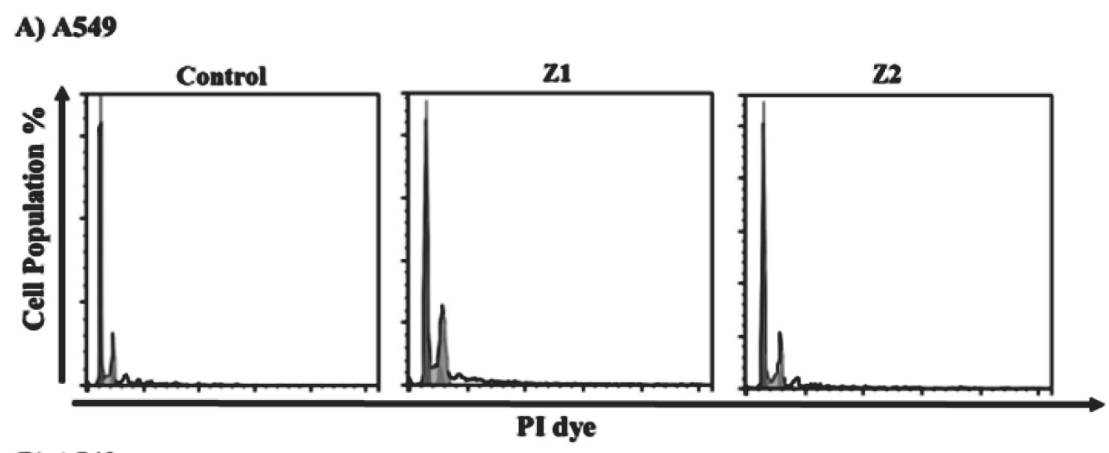

\section{B) A549}
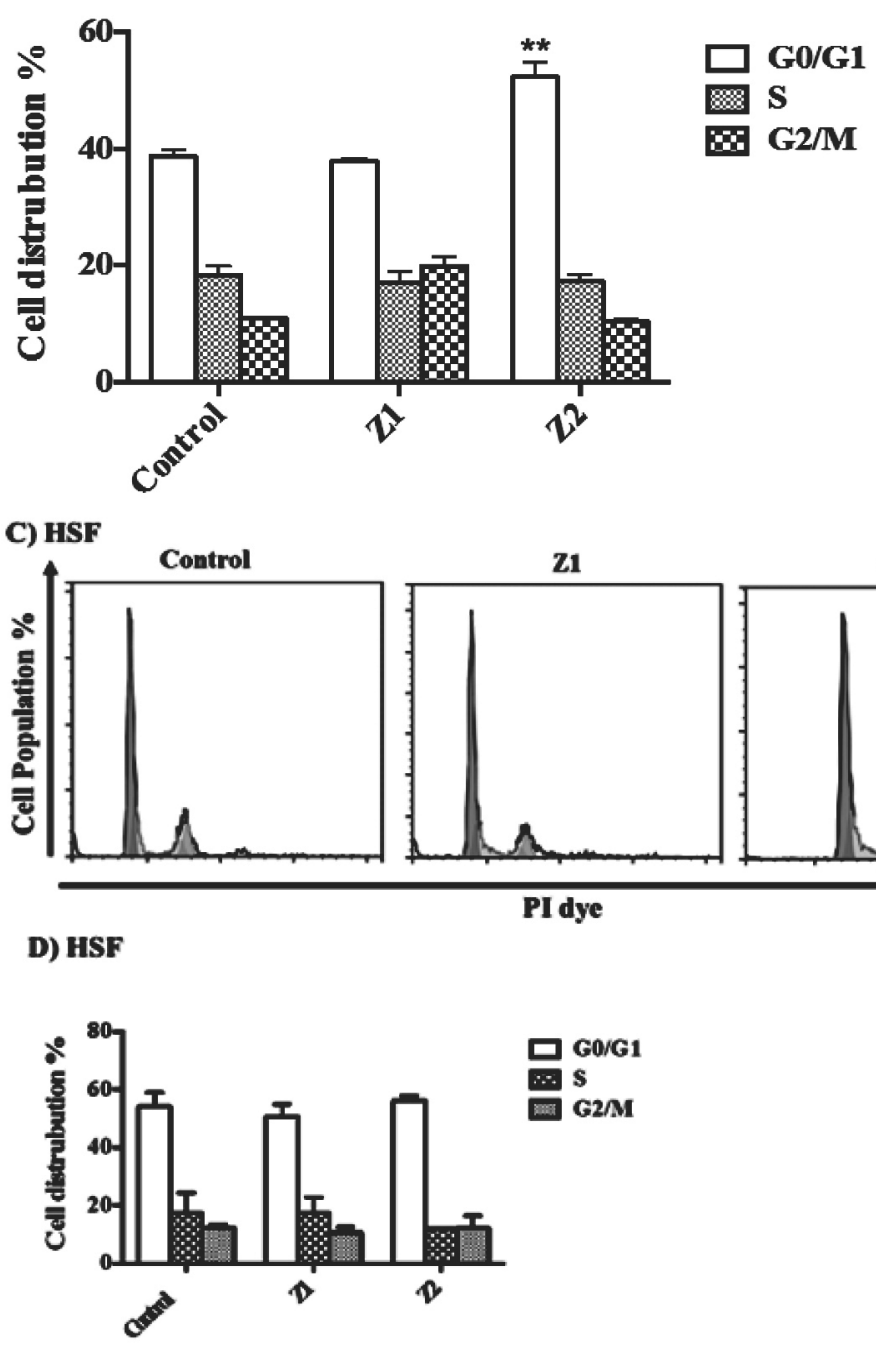

Figure 4. Cell cycle arrest in A549 and HSF cells treated with Z1 and Z2 for 24 h by flow cytometry. Represented values are the means of three independent experiments $(n=3 \pm$ SEM). Comparisons of means were made using the Kruskal-Wallis test followed by Dunn's test (**P ${ }^{*}$ 0.01). A) A549 cells treated with $Z_{1}$ and $Z_{2}$ for 24 h. B) Effects of $Z_{1}$ and $Z_{2}$ treatments on A549 cell cycle distribution after $24 \mathrm{~h}$. Growth phase (G1 phase), DNA synthesis phase (S phase), and growth 2 phase (G2 phase). In each phase, cell percentages were measured by flow cytometry. C) HSF cells treated with Z1 and Z2 for 24 h. D) Effects of Z1 and Z2 on HSF cell cycle distribution after 24 h. G1 phase (growth phase), S phase (DNA synthesis phase), and G2 phase (growth 2 phase) 


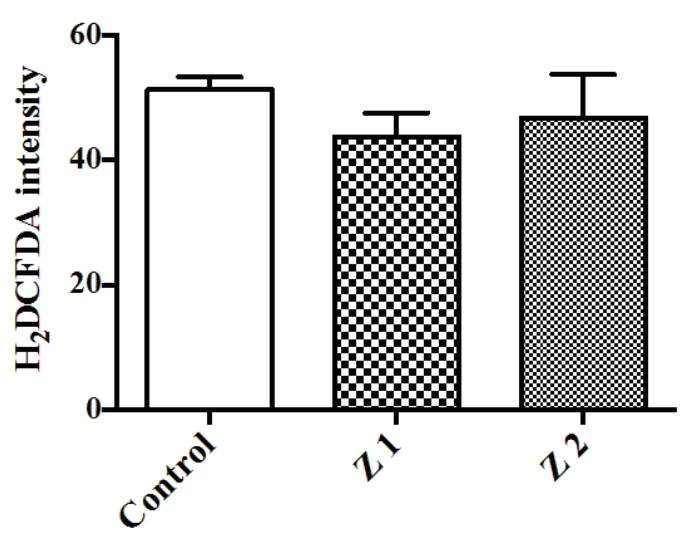

B

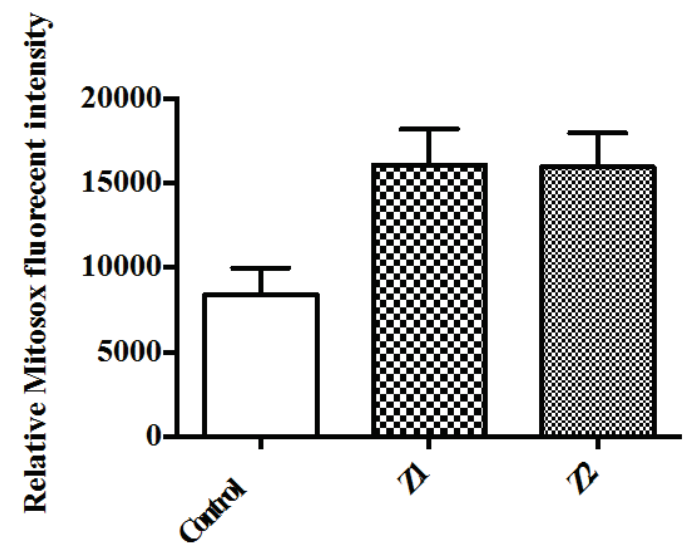

Figure 5. Measurement of cellular and mitochondrial ROS in A549 cells treated with $\mathrm{Z}_{1}$ and $\mathrm{Z} 2$ for $24 \mathrm{~h}$. The data represent the mean of three independent experiments $(n=3 \pm$ SEM). Comparisons of means were made using the Kruskal-Wallis test followed by Dunn's test. A) A549 cells treated with $\mathrm{Z}_{1}$ and $\mathrm{Z}_{2}$ for $24 \mathrm{~h}$. Cells were loaded with CM-H2DCFDA. B) A549 cells treated with $\mathrm{Z}_{1}$ and $\mathrm{Z}_{2}$ for $24 \mathrm{~h}$. Cells were loaded with MitoSOX stains. Fluorescence measured using the BioTek fluorescence microplate reader to monitor cellular and mitochondrial ROS formation. Data from both assays revealed that both Zamzam treatments (Z1 and Z2) have no significant effect on ROS formation

production of Z2 treatment was 15,965 RFU, compared to the control, which was 8,398.2 RFU (Figure $5 \mathrm{~B}$ ).

\section{Discussion}

Lung cancer incidence is considered the highest among malignant tumors. It has become the leading cause of cancer-related deaths worldwide, including in Saudi Arabia (13). Resistances to treatment with anticancer drugs and toxic side effects have resulted in the need for new anticancer treatments with little or no side effects (14). To date there are limited studies on the effects of alkaline water on cancer cells. In this study, the cytotoxic and apoptotic effects of Zamzam water on A549 cells were investigated for the first time and compared to the effects of Zamzam water on normal HSF cells.

Our results showed that the incubation of A549 cells with Zamzam water inhibited growth and proliferation and changed the morphology of A549 cells. Although it is unclear which component of Zamzam water affects the proliferation of cancer cells, it is presumed that the combined ionic actions of several minerals such as calcium, magnesium, lead, arsenate, lithium, cadmium-zinc combinations and selenium may play an important role in mediating the inhibition of proliferation of cancer cells. Our results were in contrast to previous studies that have shown that minerals such as lead, arsenate (15), lithium (16), cadmium-zinc combinations (17), and selenium (18), are capable of inhibiting the proliferation of normal and cancerous cells. Interestingly, the proliferation of HSF cells was not affected by treatment of Zamzam water, suggesting that this water might have selective cytotoxic effects, but the exact mechanism is unclear.

Pettersson et al. (19) have found that $\mathrm{As}_{2} \mathrm{O}_{3}$ induced small cell lung carcinoma (SCLC) cytotoxicity and has been shown to involve several different cell death pathways (apoptosis and necrosis). Moreover, cell death is mainly due to caspase-independent necrotic cell death, whereas the involvement of apoptosis is more cell line-dependent (19). Our results indicate that $\mathrm{Z} 1$ treatment did not induce cell death in A549 lung cancer cells. On the other hand, Z2 treatment caused necrotic cell death. These effects could be due to the unique combination of minerals in Zamzam water, arsenic and cadmium might be responsible for inducing cell death in A549 cells. Furthermore, the high $\mathrm{pH}$ value of Zamzam water is another important feature, as 
Original Article | Anticancer effects of Zamzam water in lung cancer cell line

the $\mathrm{pH}$ of Zamzam ranges from 7.9-8 compared to the ordinary water, which ranges from $6.5^{-8}$ $(11,12)$. Studies on cancer have shown that the oral administration of sodium bicarbonate increases the extracellular $\mathrm{pH}$ of tumors and reduces the formation of spontaneous metastasis (20). The extracellular $\mathrm{pH}$ of malignant tumors is acidic ( $\mathrm{pH}$ 6.5-6.9) compared to the $\mathrm{pH}$ of normal tissues, which is more alkaline $(\mathrm{pH} 7.2-$ 7.5) (21).

In normal cells, ROS plays an important role in regulating various biological pathways. The cell balances the generation of ROS thereby controlling it. In our study, ROS level in A549 cell line was investigated to assess the role of ROS in the induction of apoptosis after exposure to Zamzam treatments. Our data demonstrated that cellular ROS formation and mitochondrial ROS production were not significantly induced in A549 cells.

To further elucidate the possibility of cell growth arrest, cell cycle phases were evaluated using a flow cytometry assay. Our data showed that cells were arrested in the Go/G1 phase for Z2-treated cells, while Z1-treated cells were unaffected. The percentages of A549 cells in the Go/G1 phase were $38.6 \%, 37.9 \%$, and $52 \%$ for the control, $\mathrm{Z} 1$, and $\mathrm{Z} 2$ treatments $(P \leq 0.01)$, respectively. The percentage of cells in the G2/M phase increased in cells treated with $\mathrm{Z} 1$, with percentages of $10.8 \%, 20 \%$, and $10.4 \%$ for the control, Z1, and $\mathrm{Z}_{2}$ treatments, respectively. It was reported previously that cancer cells treated with arsenic trioxide were arrested at either the $\mathrm{G}_{1}$ or the $\mathrm{G} 2 / \mathrm{M}$ phase (22). In addition, it has been found that arrest in G2/M phase that occurs in human cancer cell lines by arsenic trioxide is due to an increase in cyclin B level, a regulatory protein involved in mitosis $(23,24)$. De Groot and his colleagues (25) observed a significant accumulation of renal cells in the G2 phase after lithium treatment when compared to their controls. It is well known that cyclin D1 and cyclin $\mathrm{E}$ are regulatory proteins that control the transition from $\mathrm{G} 1$ to $\mathrm{S}$ phase, whereas, cyclin B1 regulates the progression of the G2/M phase. Recently, a study reported that a lowconcentration of inorganic arsenic inhibits the proliferation of $\mathrm{C}_{2} \mathrm{C}_{2}$, myoblasts cells by inducing $\mathrm{G} 1$ and $\mathrm{G} 2 / \mathrm{M}$ phase cell-cycle arrest due to the decrease in the protein expressions of cyclin D1, cyclin E, and cyclin B1 (26). In this study, it was assumed that the arresting effect of $Z_{1}$ and $Z_{2}$ in A549 cells might be due to the decreased levels of cyclin D1, cyclin E, and cyclin B1 caused by both the effect of both the alkaline
$\mathrm{pH}$ and the elements found naturally in Zamzam water. Our results revealed that HSF cells were unaffected by both Zamzam water treatments. It was demonstrated that the concentrations of calcium and magnesium ions in Zamzam water were almost double the concentrations found in bottled water (8). Calcium has been implicated in the induction of apoptosis via the activation of caspase 12. Previous reports have suggested that the intake of calcium reduces the risk of colon and breast cancers $(27,28)$. Moreover, magnesium deficiency is also associated with the metastasis of cancer cells. Thus, Zamzam water may be a beneficial source, providing the proper ratio of calcium and magnesium and other elements. However, previous research studies have reported that alkaline-reduced water has potent antioxidant activity and anticancer effects and it has been shown to protect DNA from oxidative damage (29).

\section{Conclusion}

In conclusion, according to the results obtained from all previous experiments, Zamzam water might be a promising anticancer agent. Further researches are needed on the different types of cancer cell lines to investigate the cytotoxic and anticancer effects of Zamzam water on these cancers. In addition, in vivo studies are necessary to investigate the effects of Zamzam water on experimental animals with induced cancers.

\section{Acknowledgments}

The authors are grateful to The General Presidency of the Affairs of the Two Holy Mosques for providing Zamzam water samples.

\section{Conflicts of Interests}

None

\section{Authors' Contributions}

Conception and design: UO

Analysis and interpretation of the data: UO

Drafting of the article: SR

Critical revision of the article for important intellectual content: HAD

Final approval of the article: AA

Provision of study materials: HAD

Statistical expertise: AA 
Administrative, technical, or logistic support: SMA

\section{Correspondence}

Dr Ulfat M. Omar

Assistant Professor

MSc (King Abdulaziz University), PhD (University of Surrey)

King Abdulaziz University,

Faculty of Sciences, Biochemistry Department, Jeddah, P.O. Box 40288,

Zip code 21499, Saudi Arabia.

Tel: +966503675685

E-mail: uomer@kau.edu.sa

\section{References}

1. Lan D, Zhang X, He R, Tang R, Li P, He Q, Chen G. MiR-133a is downregulated in non-small cell lung cancer: A study of clinical significance. Eur J Med Res. 2015;20(1):50. https://doi. org/10.1186/s40001-015-0139-Z

2. Molina JR, Yang P, Cassivi SD, Schild SE, Adjei AA. Non-small cell lung cancer: Epidemiology, risk factors, treatment, and survivorship. Mayo Clin Pro. 2008;83(5):584-594. https://doi. org $/ 10.4065 / 83.5 .584$

3. Wang F, Lou J, Cao Y, Shi X, Wang P, Xu J, Sun R, Rao J, Huang P, Pan S, Wang H. miR-638 is a new biomarker for outcome prediction of non-small cell lung cancer patients receiving chemotherapy. Exp Mol Med. 2015;47(5):e162. https://doi.org/10.1038/emm.2015.17

4. Varner GR. Sacred Wells: A study in the history, meaning, and mythology of holy wells and waters. 2nd ed. New York (NY): Algora; 2009.

5. Mooventhan A, Nivethitha L. Scientific evidencebased effects of hydrotherapy on various systems of the body. N Am J Med Sci. 2014;6(5):199-209. https://doi.org/10.4103/1947-2714.132935

6. Kim S, Chun SY, Lee DH, Lee KS, Nam KS. Mineral-enriched deep-sea water inhibits the metastatic potential of human breast cancer cell lines. Int $J$ Oncol. 2013;43(5):1691-1700. https://doi.org/10.3892/ijo.2013.2089

7. Nassini R, Andre E, Gazzieri D, De siena, G, Zanasi A, Geppetti P, Materazzi S. A bicarbonatealkaline mineral water protects from ethanolinduced hemorrhagic gastric lesions in mice. Biol
Pharm Bull. 2010;33(8):1319-1323. https://doi. org/10.1248/bpb.33.1319

8. Shomar B. Zamzam water: Concentration of trace elements and other characteristics. Chemosphere. 2012;86(6):600-605. https://doi.org/10.1016/j. chemosphere.2011.10.025. Epub 2011 Dec 3.

9. Khalid N, Ahmad A, Khalid S, Ahmed A, Irfan M. Mineral composition and health functionality of zamzam water: A review. Int $J$ Food Prop. 2014;17(3):661-677. https://doi.org/10.1080/10 942912.2012.660721

10. Al-Ghamdi S. Inhibition of calcium oxalate nephrotoxicity with Zamzam water. Open J Prev Med. 2012;2(1):67-71. https://doi.org/10.4236/ ojpm.2012.21010.

11. Bamosa A, Elnour A, Kaatabi $\mathrm{H}$, Al Meheithif A, Aleissa K, Al-Almaie S. Zamzam water ameliorates oxidative stress and reduces hemoglobin A1c in type 2 diabetic patients. $J$ Diabetes Metab. 2013;4:249. https://doi. org/10.4172/2155-6156.1000249

12. Al Meheithif A, Elnour A, Bamosa A, Aleissa K. Antioxidant effects of Zamzam water in normal rats and those under induced-oxidant stress. $J$ Med Plant Res. 2012;6(42):5507-5512. https:// doi.org/10.5897/JMPR12.740

13. Alamoudi OS. Lung cancer at a university hospital in Saudi Arabia: A four-year prospective study of clinical, pathological, radiological, bronchoscopic, and biochemical parameters. Ann Thorac Med. 2010;5(1):30-36. https://doi.org/10.4103/18171737.58957

14. Moyo B, Mukanganyama S. Antiproliferative activity of T. welwitschii extract on Jurkat T cells in vitro. Biomed Res Int. 2015; 817624. https:// doi.org/10.1155/2015/817624

15. Corbit R, Ebbs S, King ML, Murphy LL. The influence of lead and arsenite on the inhibition of human breast cancer MCF-7 cell proliferation by American ginseng root (Panax quinquefolius L.). Life Sci. 2006;78(12):1336-1340. https://doi. org/10.1016/j.lfs.2005.07.010

16. Beyaert R, Vanhaesebroeck B, Suffys P, Van Roy F, Fiers W. Lithium chloride potentiates tumor necrosis factor-mediated cytotoxicity in vitro and in vivo. Proc Nat Acad Sci USA. 1989;86(23):9494-9498. 
Original Article | Anticancer effects of Zamzam water in lung cancer cell line

17. Remez I, Rabkin L, Veksler H, Baumane M. Cytotoxicity of cadmium, selenium, zinc and copper to mouse myeloma $\mathrm{Sp} 2 / \mathrm{o}$ cells as measured by the MTT assay. Altern Lab Anim. 1999;28(3):473-476.

18. Griffin AC. The chemopreventive role of selenium in carcinogenesis. In: MS Arnott, Van Eys J, editors. Molecular interrelations of nutrition and cancer. New York (NY): River Press; 1982. p. 401-408.

19. Pettersson HM, Pietras A, Persson MM, Karlsson J, Johansson L, Shoshan MC, Påhlman S. Arsenic trioxide is highly cytotoxic to small cell lung carcinoma cells. Mol Cancer Ther. 2009;8(1):160-170. https://doi. org/10.1158/1535-7163.MCT-08-0595

20. Robey IF, Baggett BK, Kirkpatrick ND, Roe DJ, Dosescu J, Sloane BF, Gillies RJ. Bicarbonate increases tumor $\mathrm{pH}$ and inhibits spontaneous metastases. Cancer Res. 2009;69(6):2260-2268. https://doi.org/10.1158/ooo8-5472.CAN-075575. Epub 2009 Mar 10.

21. Robey IF, Martin NK. Bicarbonate and dichloroacetate: Evaluating $\mathrm{pH}$ altering therapies in a mouse model for metastatic breast cancer. BMC Cancer. 2011;11:235. https://doi. org/10.1186/1471-2407-11-235

22. Waxman S, Anderson KC. History of the development of arsenic derivatives in cancer therapy. Oncologist. 2001;6 (Suppl 2):3-10. https://doi.org/10.1634/theoncologist.6suppl_2-3
23. King RW, Jackson PK, Kirschner MW. Mitosis in transition. Cell. 1994;79(4):563-571. https://doi. org/10.1016/0092-8674(94)90542-8

24. Ling YH, Jiang JD, Holland JF, Perez-Soler R. Arsenic trioxide produces polymerization of microtubules and mitotic arrest before apoptosis in human tumor cell lines. Mol Pharmacol. 2002;62(3):529-538. https://doi.org/10.1124/ mol.62.3.529

25. De Groot T, Alsady M, Jaklofsky M, Otte-Höller I, Baumgarten R, Giles RH, Deen PM. Lithium causes G2 arrest of renal principal cells. $J$ Am Soc Nephrol. 2014;25(3):501-510. https://doi. org/10.1681/ASN.2013090988. Epub 2014 Jan 9.

26. Liu SH, Yang RS, Yen YP, Chiu CY, Tsai K S, Lan KC. Low-concentration arsenic trioxide inhibits skeletal myoblast cell proliferation via a reactive oxygen species-independent pathway. PloS One. 2015;10(9):e0137907. https://doi.org/10.1371/ journal.pone.0137907. eCollection 2015

27. Cui Y, Rohan TE. Vitamin D, calcium, and breast cancer risk: a review. Cancer Epidemiol. Biomarkers Prev. 2006;15(8):1427-1437. https://doi.org/10.1158/1055-9965.EPI-o6-0075

28. Lappe JM, Travers-Gustafson D, Davies KM, Recker R, Heaney RP. Vitamin D and calcium supplementation reduces cancer risk: results of a randomized trial. Am J Clin Nutr. 2007;85(6): 1586-1591.

29. Lee KJ, Park SK, Kim JW, Kim GY, Ryang YS, Kim GH, Kim HW. Anticancer effect of alkaline reduced water. International Conference on Mind Body Science: Physical and physiological approach joint with the eighteenth symposium on life information science. $J$ Intl Soc Life Info Sci. 2004;22(2):302-305. 